\title{
Wild Plants for the Phytostabilization of Phosphate Mine Waste in Semi-Arid Environments: A Field Experiment
}

\author{
Hamza Zine ${ }^{1, *(1)}$, Sara Elgadi $^{1}\left({ }^{10}\right.$, Rachid Hakkou ${ }^{2,3}$, Eleni G. Papazoglou ${ }^{4}$, Laila Midhat ${ }^{5}$ \\ and Ahmed Ouhammou ${ }^{1}$ \\ 1 Laboratory of Microbial Biotechnology, Agrosciences and Environment, Faculty of Sciences- Semlalia, \\ Cadi Ayyad University, Marrakech 40000, Morocco; sara.elgadi@ced.uca.ma (S.E.); \\ ouhammou@uca.ac.ma (A.O.) \\ 2 IMED-Lab, Faculty of Sciences and Technology, Cadi Ayyad University, Marrakech 40000, Morocco; \\ r.hakkou@uca.ma \\ 3 Mining Environment \& Circular Economy (EMEC) Program, Mohammed VI Polytechnic University (UM6P), \\ Ben Guerir 43150, Morocco \\ 4 Laboratory of Systematic Botany, Department of Crop Science, Agricultural University of Athens, \\ 11855 Athens, Greece; elpapazo@aua.gr \\ 5 National Center for Research and Studies on Water and Energy, CNEREE, Department of Biology, \\ Faculty of Sciences-Semlalia, Cadi Ayyad University, Marrakech 40000, Morocco; laila.midhat@gmail.com \\ * Correspondence: hamza.zine@edu.uca.ac.ma
}

check for

updates

Citation: Zine, H.; Elgadi, S.; Hakkou, R.; Papazoglou, E.G.; Midhat, L.; Ouhammou, A. Wild Plants for the Phytostabilization of Phosphate Mine Waste in Semi-Arid Environments: A Field Experiment. Minerals 2021, 11, 42. https://doi.org/10.3390/ $\min 11010042$

Received: 2 December 2020 Accepted: 21 December 2020 Published: 31 December 2020

Publisher's Note: MDPI stays neutral with regard to jurisdictional clai$\mathrm{ms}$ in published maps and institutional affiliations.

Copyright: (C) 2020 by the authors. Licensee MDPI, Basel, Switzerland. This article is an open access article distributed under the terms and conditions of the Creative Commons Attribution (CC BY) license (https:// creativecommons.org/licenses/by/ $4.0 /)$.

\begin{abstract}
The management of mine waste has become an urgent issue, especially in semi-arid environments. In this context, and with an aim to inhibit the oxidation of the sulfide tailings of the abandoned mine of Kettara in Morocco, a store-and-release (SR) cover made of phosphate mine waste $(\mathrm{PW})$ was implemented. In order to guarantee its long-term performance, phytostabilization by local wild plant species is currently the most effective and sustainable solution. This study aimed to assess the growth performance and phytostabilization efficiency of five local wild plant species to grow on the SR cover made of PW. A field experiment was conducted for two growing seasons (2018 and 2019), without amendments and with the minimum of human care. PW and the aboveground and belowground parts of the studied plant species were collected and analyzed for $\mathrm{As}, \mathrm{Cd}, \mathrm{Cu}, \mathrm{Ni}$, and $\mathrm{Zn}$. The bioconcentration factor (BCF) and translocation factor (TF) were also calculated. Despite the hostile conditions of the mining environment, the five plant species showed promising growth performances as follows: Atriplex semibaccata > Vicia sativa $>$ Launaea arborescens $>$ Peganum harmala $>$ Asparagus horridus. The five plants showed high accumulation capacity of the trace elements, with the highest concentrations in belowground tissue. Principal component analysis distinguished A. semibaccata as having a high concentration of $\mathrm{Cu}$ and As, while Asparagus horridus had higher concentrations of $\mathrm{Cd}$ and $\mathrm{Zn}$. In contrast, P. harmala, V. sativa, and L. arborescens demonstrated affinity regarding Ni. According to the $\mathrm{BCF}(<1)$ and TF $(<1)$, these plant species could be used as effective phytostabilizers of the studied trace elements. The present study showed that local wild plant species have a great potential for the phytostabilization of PW, and could ensure the long-term efficiency of SR cover.
\end{abstract}

Keywords: phytostabilization; phosphate mine waste; local wild plant; trace elements; semi-arid environment; field experiment

\section{Introduction}

Morocco has a long-standing history and an important role in the mining trade due to the diversity of its mineral resources [1]. It exploits many minerals, mainly phosphate, lead, copper, gold, silver, and barite, among others [2]. Phosphate mining is considered a fundamental pillar of the Moroccan economy [3]. According to the U.S. Geological Survey, Mineral Commodity Summaries [2], Morocco is the world leader in terms of exports of phosphate, with $31 \%$ of the market and 50 billion tons in reserve, and the 
second in terms of production, with 36 million tons produced in 2019. Nonetheless, this large production has come at a high environmental cost [4]. During open-pit mining, millions of tons of waste are removed to access the phosphate rocks; they are generally stripped off and set aside in storage facilities, or are placed in disposal areas, and become exposed to atmospheric phenomena $[5,6]$. The accumulation of these waste rocks negatively affects the neighboring environment by disrupting the balance of the ecosystem, damaging the esthetics of the landscape, and is a potential threat of the local population's health given the cadmium concentration occurring in this material $[4,7,8]$. Despite the fact that, according to Haneklous et al. [9] and Tulsidas et al. [10], the concentration of uranium in the exported phosphate rock was $130 \mathrm{mg} \mathrm{kg}^{-1}$ and $97 \mathrm{mg} \mathrm{kg}^{-1}$, respectively, according to Hakkou et al. [11] and Bossé et al. [12], phosphate mine waste (PW) did not contain any traces of this element. The recycling of this economic waste may be beneficial in a sustainable development context $[8,13,14]$. Research conducted by Hakkou et al. $[7,13]$, Bossé et al. [12], Ouakibi et al. [6], and Knidiri et al. [15] showed the feasibility of using such material from an operating phosphate mine in the Gantour sedimentary basin (Morocco) to control acid mine drainage generated by coarse tailings from the Kettara mine.

Studies $[6,7,9,12,15]$ were carried out in the context of the reclamation project using PW as a cover for the sulfide tailings of the abandoned mine in Kettara [6,12,15,16]. In semi-arid areas, this system, called store-and-release (SR) cover, ensures the inhibition of the sulfide oxidation reaction by limiting water infiltration through the sulfidic tailings of mines $[12,17,18]$. Thus, the overall design of this reclamation project required the collection of the abandoned mine tailings of Kettara, then an SR cover (with a thickness of $100 \mathrm{~cm}$ ) made of PW would be placed over the tailings [7,12,13]. Due to the scarcity of vegetative cover on and around the SR systems, rain and wind can remove fine particles, threatening the cover's sustainability, and reducing the thickness necessary for preventing water infiltration [18]. Thus, according to Mendez and Maier [19], Bolan et al. [20], and Aznar-Sánchez et al. [21], biological methods of phytoremediation are becoming one of the best sustainable solutions for the management of mining waste [22]. Indeed, the use of plants to manage mining waste has received great interest worldwide [23]. Phytomanagement of mining waste entails numerous techniques, including phytostabilization, which attempts to reduce the mobility of pollutants in the soil by absorbing them into the plants' roots $[16,24-27]$.

From this perspective, phytostabilization using a vegetation cap based on local wild plant species planted directly into an SR cover will be an effective and ecological tool for protecting the integrity of the cover and ensuring its long-term performance [18]. Moreover, the main functions of this vegetation cap are to reduce the availability of trace elements, isolate waste from the surrounding environment, mitigate the eroding effects of wind and water, and ensure the esthetic improvement of the landscape [28].

The use of plants tolerant of poor soil conditions, seasonal drought, and high temperatures is required [29]. In this sense, local wild plant species have distinct advantages as they usually possess high tolerance of semi-arid environmental conditions [30]. The roots hold the substrate and immobilize metal and metalloid trace elements, e.g., $\mathrm{Zn}, \mathrm{Cr}, \mathrm{Cd}, \mathrm{Cu}$, and As [11,12], preventing the transfer of contaminants into the surrounding ecosystem and food chain through grazing or plant harvest, especially cadmium, which is found in high concentrations in sedimentary rock phosphate [31]. Moreover, the plant roots facilitate the enhancement of soil microbiological flora [30,32]. Therefore, the choice of plant species must be made in such a way as to protect the integrity of the cover, and to ensure the rapid establishment of a stable, adaptive, easily re-generable, and self-sustaining plant community [33].

There has always been an interest in searching for local wild plants tolerant to mining waste; however, there are few studies that have evaluated the phytostabilization of mining waste by local plants under field conditions [23,34,35]. Moreover, to the best of our knowledge, no previous research has studied the potential of local wild plants in the phytostabilization of PW in the real conditions of Morocco's semi-arid environment. 
Following the preceding considerations, the question that naturally arises is the suitability or not of local wild plant species for the phytostabilization of the SR cover made of PW in a semi-arid environment. Therefore, this field experiment study aimed to evaluate and compare the performance and potential for phytostabilization of PW by five local wild plants in a semi-arid environment.

\section{Materials and Methods}

\subsection{Field Experimental Design}

The studied site is the abandoned mine in Kettara (470 masl, $31^{\circ} 51^{\prime} 36^{\prime \prime} \mathrm{N}$ and $8^{\circ} 9^{\prime} 36^{\prime \prime} \mathrm{W}$ ) located $35 \mathrm{~km}$ north-northwest of the city of Marrakech (Figure 1a,b). The area is characterized by semi-arid bioclimatic conditions [12,36].

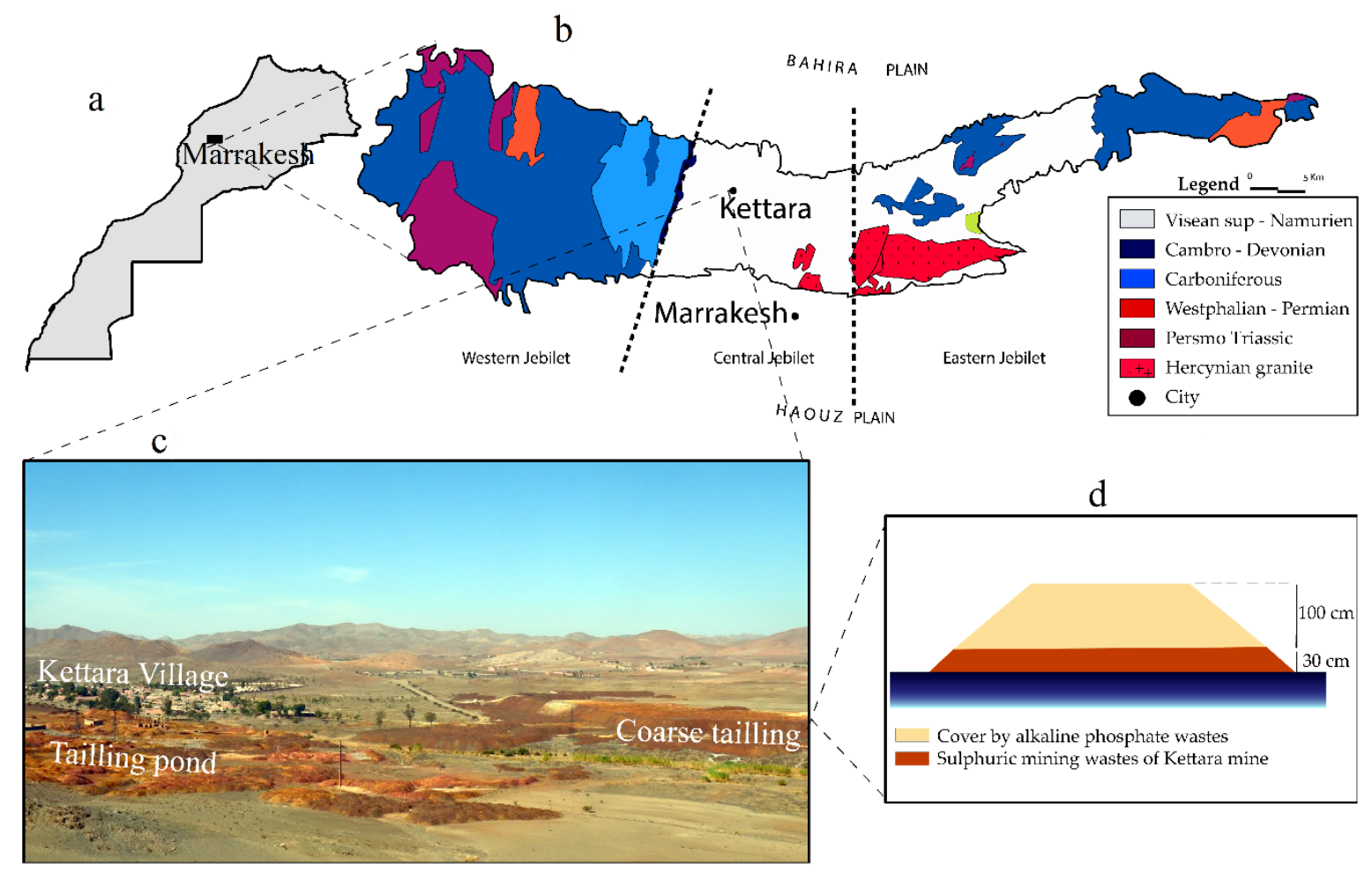

Figure 1. The localization of the abandoned mine of Kettara (a,b), tailing impoundment area (c), and the store-and-release cover design at the experimental park (d) (modified from Bossé et al. [12]).

The field experiment was performed based on a pre-designed $10 \times 10 \mathrm{~m}$ experimental plot located in the Kettara abandoned mine experimental park. The plot was designed, constructed, and equipped in order to assess the hydrogeological behavior of the SR cover made of PW [6,12] (Figure 2). Details of substrate characteristics and different thicknesses used are given in Bossé et al. [12]. This experiment was designed in order to finalize the global plan of reclamation of the Kettara abandoned mine (Figure 1d). 


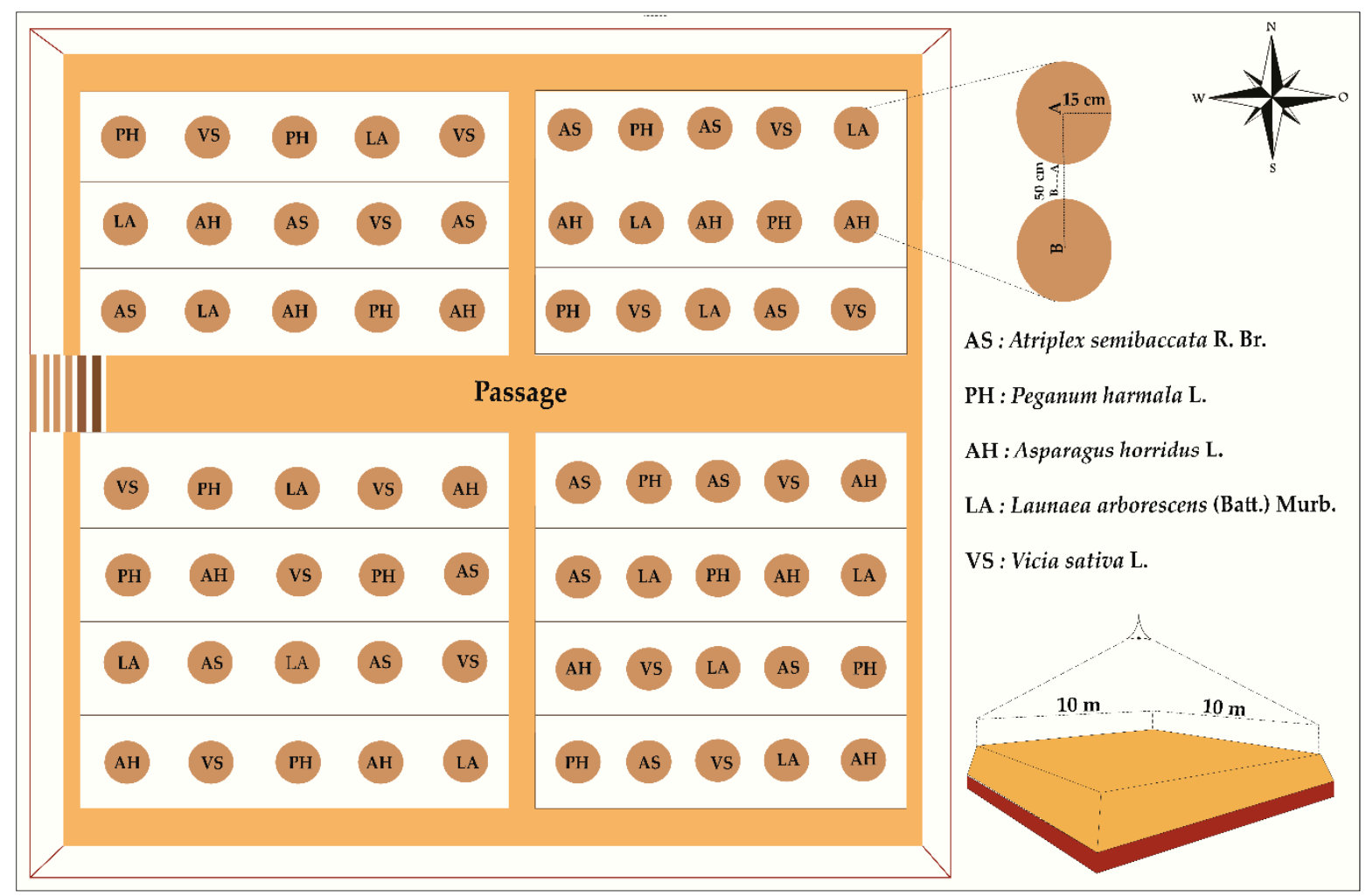

Figure 2. Schema of the experimental plot used to conduct the study.

\subsection{Plant Species}

The five plant species used in this field experiment were selected according to their performance from preliminary greenhouse results [36], and to their botanical and ecological characteristics: namely, Vicia sativa L., Asparagus horridus L., Peganum harmala L., Launaea arborescens (Batt.) Murb., and Atriplex semibaccata R. Br. Fourteen plants of each species of similar sizes, growth (2 months), and general aspects were randomly transplanted into the plot in February 2018 (Figure 2).

The experiment was conducted under local conditions without any amendments over 2 years from February 2018 to December 2019. Irrigation was only applied at the beginning of the experiment following the establishment of the seedlings, so as to better evaluate the plant performance with minimal intervention and care. Specimens of the same species were planted in agricultural soil $1 \mathrm{~km}$ away as controls and were treated and sampled in the same way.

\subsection{Plant and Soil Sampling}

In order to evaluate plant growth, two plant samplings were carried out at the end of each growing season. Shoots and leaves of each plant species were harvested, oven-dried at $70{ }^{\circ} \mathrm{C}$, and weighed to determine the average dry biomass. After the 2-year experiment, plant species were carefully collected, separated into aerial parts and roots, and stored in a plastic bag and frozen until further analysis.

PW samples were collected in the zone in contact with the belowground parts of plants. A soil sample was collected $1 \mathrm{~km}$ away from the control agricultural soil. Soil samples were mixed, homogenized, sieved to $2 \mathrm{~mm}$, and oven-dried at $60^{\circ} \mathrm{C}$ for $48 \mathrm{~h}$, then stored in polyethylene bags until further analysis. 


\subsection{Soil and Plant Tissue Analyses}

Physico-chemical soil properties were determined according to the standard procedures published in the Official Methods of Soil Analysis [37]. Fine particles were analyzed for the determination of electrical conductivity (1:5 w/v soil:water) and $\mathrm{pH}(1: 2.5 w / v$ soil:water) using an LF 92 WTW multiparameter probe (Cond-pH 1970i; WTW GmbH, Weilheim, Germany).

Trace element concentrations were determined by adding $7 \mathrm{~mL} \mathrm{HNO} 3(65 \% \mathrm{w} / \mathrm{w})$, $2 \mathrm{~mL}$ of $\mathrm{HF}(40 \% w / w)$, and $1 \mathrm{~mL}$ of $\mathrm{HClO}_{4}(60 \% w / w)$ to $500 \mathrm{mg}$ of the PW and control soil samples, previously calcinated in a muffle furnace at $500{ }^{\circ} \mathrm{C}$. Then each sample solution was diluted to $50 \mathrm{~mL}$. The samples were analyzed in triplicate for trace elements (As, $\mathrm{Cd}$, $\mathrm{Cu}, \mathrm{Ni}$, and $\mathrm{Zn}$ ) using inductively coupled plasma-atomic emission spectrometry (ICP-AES) according to ISO 22,036 (2008) [38].

Plant samples were carefully washed with tap water, followed by deionized water, oven-dried at $80^{\circ} \mathrm{C}$ for $72 \mathrm{~h}$, and then ground into fine powder using a pestle and mortar. The concentrations of trace elements in plant tissues were determined according to the method of Temminghoff and Houba [39]. Plant tissue samples (200 mg) were fully mineralized with $\mathrm{HNO}_{3}(65 \%), \mathrm{HF}(40 \%)$, and $\mathrm{H}_{2} \mathrm{O}_{2}(30 \%)$ in a microwave oven and the concentrations of trace elements ( $\mathrm{As}, \mathrm{Cd}, \mathrm{Cu}, \mathrm{Ni}$, and $\mathrm{Zn}$ ) were determined using ICP-AES (Optima 3100 RL; Perkin Elmer Waltham, MA, USA).

\subsection{Phytoremediation Factors and Phytostabilization Efficiency}

The phytostabilization efficiency of the selected plants and their accumulation capacity for trace elements in their belowground and aboveground fractions were assessed by the calculation of two key factors: the translocation factor (TF) and the bioconcentration factor $(B C F)$.

The TF indicates a plant's efficiency in translocating accumulated trace elements from its belowground parts to its aboveground parts. It is calculated according to Ali et al. [40], as in Equation (1). The BCF indicates the efficiency of a plant species to accumulate trace elements in its tissue from the surrounding substrate and is calculated according to Ali et al. [40], using Equation (2).

$$
\begin{gathered}
\mathrm{TF}=\frac{[\mathrm{MTE}]_{\text {aboveground }}}{[\mathrm{MTE}]_{\text {belowground }}} \\
\mathrm{BCF}=\frac{[\mathrm{MTE}]_{\text {aboveground }}}{[\mathrm{MTE}]_{\mathrm{PW}}}
\end{gathered}
$$

where: [MTE]: concentration of the target trace element in plant fractions. PW: phosphate waste

\subsection{Statistical Analysis}

Statistical differences in $\mathrm{Zn}, \mathrm{Cu}, \mathrm{As}, \mathrm{Ni}$, and $\mathrm{Cd}$ concentrations in different plant species and dry biomass means were assessed using one-way analysis of variance (ANOVA) followed by Tukey's post hoc test to determine the significant difference between years and plant species. All statistical analyses were performed using SPSS Statistics version 21 (IBM Corp., Armonk, NY, USA), with $p$-values $\leq 0.05$ considered statistically significant. A principal component analysis (PCA) was performed using R 4.0.3 software (R Core Team, 2020) to distinguish the tolerance preference of plant species regarding the accumulation of trace elements.

\section{Results and Discussions}

\subsection{Trace Element Content in Substrate}

The $\mathrm{pH}$, electrical conductivity (EC), and trace elements in PW and control samples are summarized in Table 1. The results showed that PW presented high concentra- 
tions of $\mathrm{Cu}\left(118.14 \pm 33.71 \mathrm{mg} \mathrm{kg}^{-1}\right)$ and $\mathrm{Zn}\left(96.09 \pm 11.23 \mathrm{mg} \mathrm{kg}^{-1}\right)$, followed by Ni $\left(21.10 \pm 2.48 \mathrm{mg} \mathrm{kg}^{-1}\right)$ and $\mathrm{Cd}\left(11.13 \pm 1.96 \mathrm{mg} \mathrm{kg}^{-1}\right)$, whereas As presented the lowest value at $9.61 \pm 1.22 \mathrm{mg} \mathrm{kg}^{-1}$. Moreover, the results showed a significant difference $(p<0.05)$ in the concentrations of $\mathrm{Cu}, \mathrm{Zn}$, and $\mathrm{Cd}$ in the PW compared with those in the control soil. According to Kabata-Pendias and Pendias [41], Kabata-Pendias [42], and Kloke et al. [43], the threshold limit concentrations values (TLVs) range from 100 to $150 \mathrm{mg} \mathrm{kg}^{-1}$ for Cu, $300 \mathrm{mg} \mathrm{kg}^{-1}$ for $\mathrm{Zn}, 50 \mathrm{mg} \mathrm{kg}^{-1}$ for Ni, and $20 \mathrm{mg} \mathrm{kg}^{-1}$ for As. Therefore, the concentrations of these trace elements $(\mathrm{Cu}, \mathrm{Zn}, \mathrm{Ni}$, and $\mathrm{As})$ present in $\mathrm{PW}$ do not exceed the level of the environmental quality standards, except for the concentration of $\mathrm{Cd}$, which exceeded the TLV $\left(3 \mathrm{mg} \mathrm{kg}^{-1}\right)$, which can be considered as a potential source of surrounding environment contamination [43]. These results are consistent with those of Hakkou et al. [11]; the same authors showed, using kinetic testing, that PW does not exhibit a significant generation of contaminants despite the presence of the abovementioned contaminants. The PW had a pH near neutrality $(7.42 \pm 0.4)$ and a relatively high EC $(285.2 \pm 9.4 \mu \mathrm{s} / \mathrm{cm})$. The results of Zine et al. [36] showed similar values for the same substrates.

Table 1. Trace elements, major elements, $\mathrm{pH}$, and electric conductivity of the phosphate mine waste.

\begin{tabular}{cccc}
\hline Parameter & Unit & Phosphate Mine Waste & Control Soil \\
\hline $\mathrm{As}$ & $\left(\mathrm{mg} \mathrm{kg}^{-1}\right)$ & $9.61 \pm 1.22^{\mathrm{c}}$ & $12.66 \pm 1.26^{\mathrm{c}}$ \\
\hline $\mathrm{Cd}$ & $\left(\mathrm{mg} \mathrm{kg}^{-1}\right)$ & $11.13 \pm 1.96^{\mathrm{c}}$ & $0.41 \pm 0.16^{\mathrm{d}}$ \\
\hline $\mathrm{Cu}$ & $\left(\mathrm{mg} \mathrm{kg}^{-1}\right)$ & $23.12 \pm 2.11^{\mathrm{b}}$ & $51.48 \pm 14.32^{\mathrm{a}}$ \\
\hline $\mathrm{Ni}$ & $\left(\mathrm{mg} \mathrm{kg}^{-1}\right)$ & $21.10 \pm 2.48^{\mathrm{b}}$ & $25.21 \pm 1.62^{\mathrm{c}}$ \\
\hline $\mathrm{Zn}$ & $\left(\mathrm{mg} \mathrm{kg}^{-1}\right)$ & $96.09 \pm 11.23^{\mathrm{a}}$ & $81.50 \pm 9.11^{\mathrm{a}}$ \\
\hline $\mathrm{pH}$ & - & $7.42 \pm 0.4^{\mathrm{c}}$ & $7.15 \pm 0.2^{\mathrm{c}}$ \\
\hline Electrical conductivity $(\mathrm{EC})$ & $(\mu \mathrm{s} / \mathrm{cm})$ & $285.2 \pm 9.4^{\mathrm{a}}$ & $340.6 \pm 6.31^{\mathrm{b}}$ \\
\hline
\end{tabular}

Values are presented as mean $\pm \mathrm{SD}(n=3)$. Different letters in the same row indicate significant differences $(p<0.05)$.

\subsection{Plant Biomass}

The plant biomass values of the studied plants are presented in Figure 3. Comparisons of the biomass produced by each species revealed significant differences between plant species in both 2018 and 2019. The growth of the seedlings of Atriplex semibaccata R. Br. and Vicia sativa L., followed by Launaea arborescens (Batt.) and Peganum harmala L., Murb., demonstrated a high adaptation to the harsh climatic conditions and the plants did not seem be experiencing stress due to the hostile characteristics of the PW. In contrast, the plants of Asparagus horridus L. showed low biomass values, which reflects the species' relatively limited capacity to adapt to environmental stress, since according to Zine et al. [36], it showed a higher growth speed in a greenhouse experiment, in contrast to other species such as Launaea arborescens (Batt.) and Peganum harmala L., Murb.

Although we observed a contrasting performance between 2018 and 2019, notably for Atriplex semibaccata and Vicia sativa (Figure 3), these differences were not considered statistically significant $(p<0.05)$, probably due to the contrast in terms of precipitation between 2018 and 2019. In general, chamaephyte growth is known to be highly modified by the precipitation rate $[44,45]$. A. semibaccata reached impressive values after 2 years of cultivation, with an average annual productivity per plant of almost $135.35 \pm 6.90 \mathrm{~g} \mathrm{~m}^{-2}$. Pioneer plant species, such as Vicia sativa and A. semibaccata, have been reported to be characterized by a high tolerance to mining waste, with a rapid growth rate and excellent soil coverage $[46,47]$. These properties confer advantages to these kinds of plant species as promising candidates for the phytomanagement of mining waste. According to Conesa et al. [48], Moreno-Jiméenez et al. [49], and Yuanyuan et al. [50], in general, these local plant species are often genetically better equipped in terms of survival, growth, and the ability to reproduce under environmental stress than other exotic plant species. 


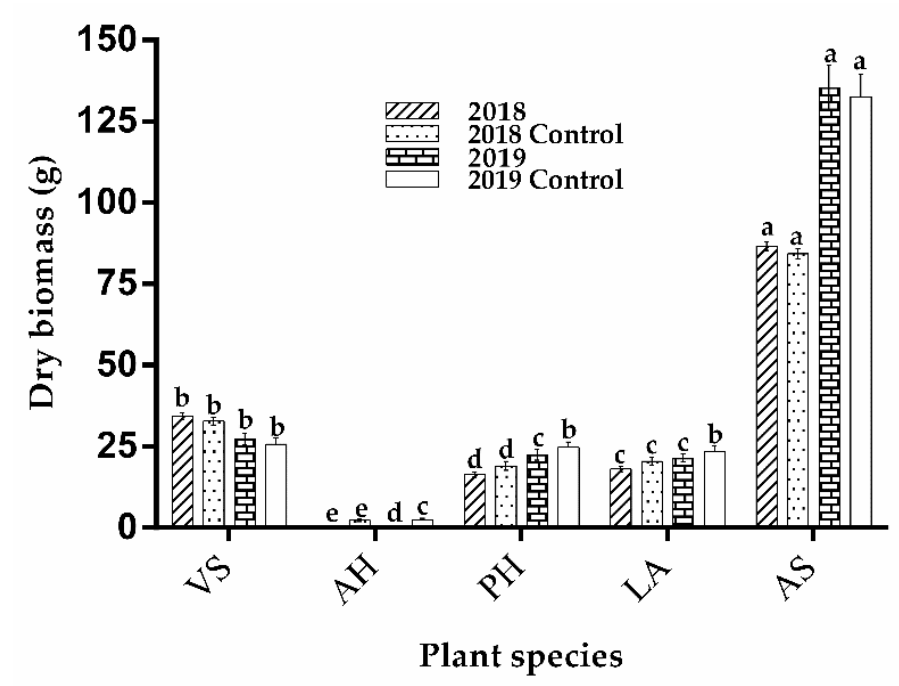

Figure 3. Aboveground dry biomass per plant measured at the end of each growing season for the five species: VS: Vicia sativa L., AH: Asparagus horridus L., PH: Peganum harmala L., LA: Launaea arborescens (Batt.) Murb., and AS: Atriplex semibaccata R. Br. Note: Different letters above columns of different plant species indicate significant differences $(p<0.05)$.

\subsection{Trace Element Concentrations in Plant Species}

The concentrations of metal and metalloid trace elements in aboveground and belowground plant fractions were evaluated for the five plant species, and the corresponding results are presented in Figure 4. The results show that $\mathrm{As}, \mathrm{Cd}, \mathrm{Cu}, \mathrm{Ni}$, and $\mathrm{Zn}$ concentrations in aboveground plant parts (shoots) were very low compared with those in belowground tissues (roots). Concerning the accumulation of the studied trace elements, the results reveal a common observation for Vicia sativa L., Peganum harmala L., Launaea arborescens (Batt.) Murb., and Atriplex semibaccata R. Br, as the concentrations of the different trace elements in the aboveground and belowground parts of these five plant species all obeyed the following order: $\mathrm{Zn}>\mathrm{Cu}>\mathrm{Ni}>\mathrm{Cd}>\mathrm{As}$. In contrast, the results for Asparagus horridus $\mathrm{L}$. followed a different order: $\mathrm{Zn}>\mathrm{Cu}>\mathrm{Cd}>\mathrm{Ni}>$ As.

For each metal considered, there was a significant difference $(p<0.05)$ between plant species, except for $\mathrm{Ni}$, which shows similar values, especially in the aboveground parts of Vicia sativa L., Asparagus horridus L., and Peganum harmala L.

Trace element concentrations varied in the aboveground and belowground parts according to the species (Figure 4). Among the five species, Atriplex semibaccata R. Br. and Vicia sativa L. had the highest concentration of As in shoots at $4.27 \pm 0.08 \mathrm{mg} \mathrm{kg}^{-1}$ $\mathrm{dw}$ and $2.14 \pm 0.07 \mathrm{mg} \mathrm{kg}^{-1} \mathrm{dw}$, and $2.23 \pm 0.08 \mathrm{mg} \mathrm{kg}^{-1} \mathrm{dw}$ and $1.91 \pm 0.31 \mathrm{mg} \mathrm{kg}^{-1}$ $\mathrm{dw}$, in roots and shoots, respectively. Asparagus horridus L. had the highest concentration of Cd, with $7.82 \pm 0.70$ and $5.75 \pm 0.75 \mathrm{mg} \mathrm{kg}^{-1} \mathrm{dw}$, followed by Vicia sativa L., with $3.59 \pm 0.45$ and $3.60 \pm 0.63 \mathrm{mg} \mathrm{kg}^{-1} \mathrm{dw}$ in roots and shoots, respectively. Concerning the concentration of $\mathrm{Cu}$, Atriplex semibaccata $\mathrm{R}$. Br. had the highest concentrations in roots and shoots, with values at $29.03 \pm 2.01$ and $17.39 \pm 2.23 \mathrm{mg} \mathrm{kg}^{-1} \mathrm{dw}$ in roots and shoots, respectively, followed by Peganum harmala $\mathrm{L}$. with $14.11 \pm 0.19 \mathrm{mg} \mathrm{kg}^{-1} \mathrm{dw}$ in roots, and $11.80 \pm 2.90 \mathrm{mg} \mathrm{kg}^{-1} \mathrm{dw}$ in shoots. 

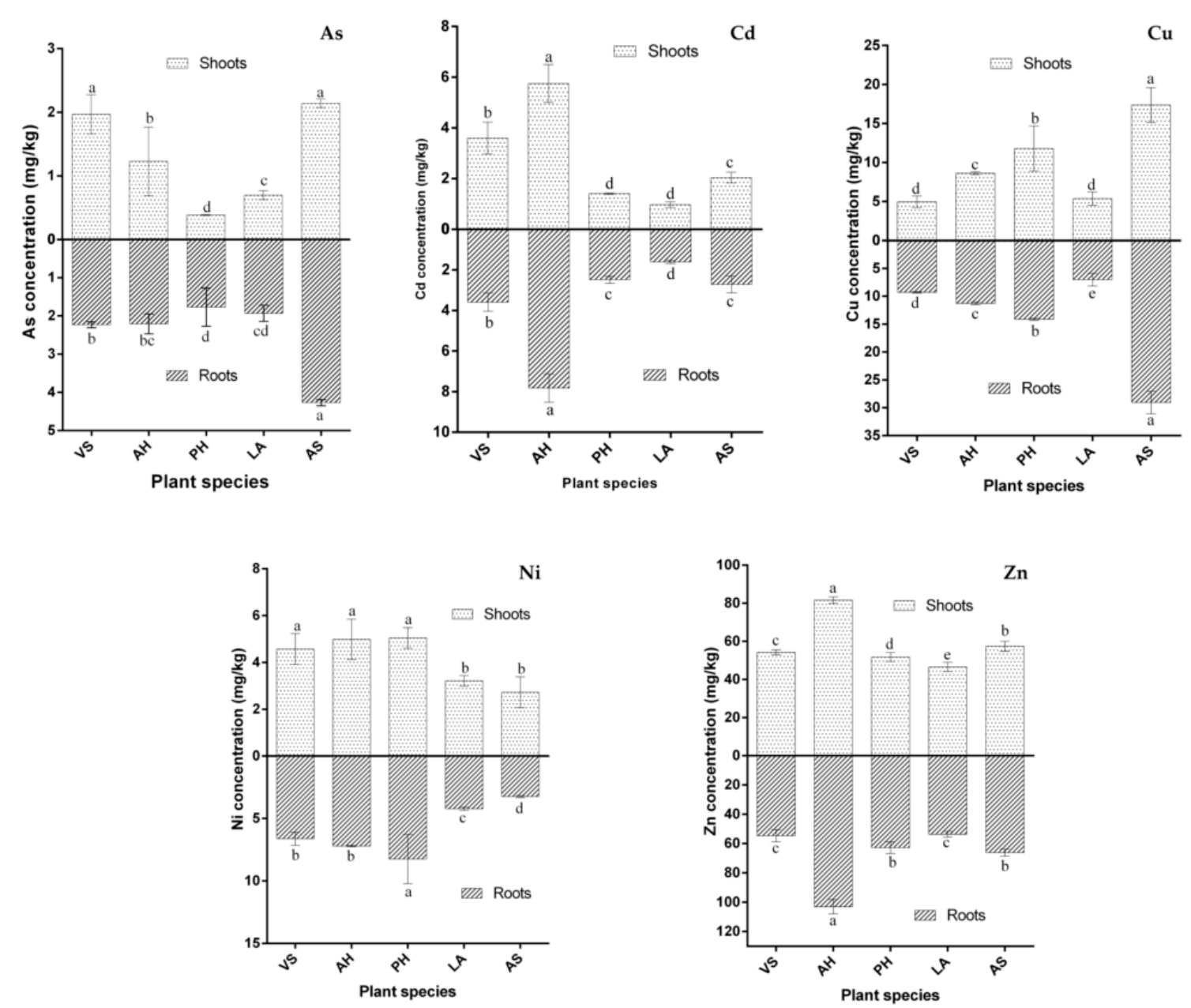

Figure 4. Concentrations of $\mathrm{As}, \mathrm{Cd}, \mathrm{Cu}, \mathrm{Ni}$, and $\mathrm{Zn}$ in shoots and roots of the five plant species. Abbreviations are the same as in the plant scheme in Figure 2.

The concentrations of As, $\mathrm{Cd}$, and $\mathrm{Cu}$ in the roots and shoots of Atriplex semibaccata R. Br. and those of Asparagus horridus L. were two or three times higher in comparison to those measured in the roots and shoots of the other species. The $\mathrm{Zn}$ concentration was higher in Asparagus horridus L. and Atriplex semibaccata R. Br. Regarding the concentrations of $\mathrm{Ni}$, the plant species can be arranged in two groups, each with similar results, the first comprising Vicia sativa L., Asparagus horridus L., and Peganum harmala L., and the second comprising Launaea arborescens (Batt.) Murb. and Atriplex semibaccata R. Br.

All concentrations of trace elements in the aboveground parts of the studied plants were below the domestic animal toxicity limits for cattle grazing according to the Committee on Minerals and Toxic Substances in Diets and Water for Animals, National Research Council [31] (As $<100 \mathrm{mg} \mathrm{kg}^{-1}, \mathrm{Cd}<10 \mathrm{mg} \mathrm{kg}^{-1}, \mathrm{Cu}<500 \mathrm{mg} \mathrm{kg}^{-1}, \mathrm{Ni}<30 \mathrm{mg} \mathrm{kg}^{-1}$, and $\mathrm{Zn}<500 \mathrm{mg} \mathrm{kg}^{-1}$ ). Thus, the harvested parts of the plants do not present a contamination threat to animal health [14]. However, according to the National Research Council [31], the concentration of $\mathrm{Cd}$, ranging from 3 to $100 \mathrm{mg} \mathrm{kg}^{-1}$, found in phosphate sedimentary rocks, could be a source of contamination of the trophic chain, even if its mobility and bioavailability to plants is highest in acid soil than in alkaline one [31]. Therefore, the aboveground biomass of these plants can be valorized and used in the production of non-food products [51,52].

\subsection{Bioconcentration and Translocation Factors}

The BCF and TF values of the five local plant species for the studied trace elements are presented in Table 2. The results showed that all BCF values were less than one for the five 
studied trace elements (As, $\mathrm{Cd}, \mathrm{Cu}, \mathrm{Ni}$, and $\mathrm{Zn}$ ). Similarly, all plants showed a TF less than 1. However, TF values were higher than BCF values for the same trace element and for the same plant species. In addition, the values of BCF reported in Table 2 are remarkably low and indicate that the concentrations of trace elements found in the aboveground parts of the five local plant species were much lower than the concentrations found in the PW.

Statistical analysis demonstrated different responses for the five plant species regarding trace elements. Lee et al. [53] reported that BCF and TF values are particularly dependent on the plant species used, on the degree of substrate contamination, its chemical properties, and on the time of year. This is due to the fact that the absorption and reaction of trace elements differs from one element to another, as well as from one species to another [54].

The assessment and selection of plants for phytomanagement for phytoremediation purposes depend on BCF and TF values [40,55]. According to Nouri et al. [56] and Ali et al. [40], both these factors are crucial in screening plants for the phytostabilization of trace elements in mining waste. Indeed, plant species with a $\mathrm{BCF}<1$ and a TF $<1$ are suitable for use in phytoremediation through phytostabilization, while plant species with both $\mathrm{BCF}$ and $\mathrm{TF}$ values greater than one are suitable for use in phytoextraction [57].

The BCF and TF values show good agreement with a previous study conducted under greenhouse conditions [36], wherein the same plant species gave similar results. Therefore, our results cast new light on and confirm the capacity of the selected local plant species for the management of PW through their phytostabilization in semi-arid environments. According to Mendez and Maier [19], the selection of suitable plant species candidates is a crucial issue, and requires specific attention. The plant species destined to be used in the phytomanagement of mining waste by phytostabilization should produce significant biomass, have a dense root system, and the translocation of trace elements from belowground to aboveground parts should be as minimal as possible; they should also be well adapted to local environmental stress. The selection of local plant species for the phytostabilization of SR made of PW requires another specific condition regarding the length of the roots of the plants. The length of the roots should not exceed $1 \mathrm{~m}$, since this is the thickness of SR required to ensure that the oxidation of the sulfide tailings of Kettara is prevented [11,12]. Therefore, this research exploited the use of chamaephytes known for their limited root system [58]. 
Table 2. Translocation factor (TF) and bioconcentration factor (BCF) of the different species sampled for each element.

\begin{tabular}{|c|c|c|c|c|c|c|c|c|c|c|}
\hline & & & BCF & & & & & $\mathrm{TF}$ & & \\
\hline Plant Species & As & $\mathrm{Cd}$ & $\mathrm{Cu}$ & $\mathrm{Ni}$ & $\mathrm{Zn}$ & As & $\mathrm{Cd}$ & $\mathrm{Cu}$ & $\mathrm{Ni}$ & $\mathrm{Zn}$ \\
\hline Vicia sativa $\mathrm{L}$. & $0.20 \pm 0.03^{\mathrm{a}}$ & $0.32 \pm 0.05^{b}$ & $0.04 \pm 0.01^{\mathrm{d}}$ & $0.21 \pm 0.03^{\mathrm{a}}$ & $0.56 \pm 0.01^{\mathrm{c}}$ & $0.89 \pm 0.15^{\mathrm{a}}$ & $1.02 \pm 0.23^{a}$ & $0.53 \pm 0.08^{b}$ & $0.69 \pm 0.12^{b}$ & $0.99 \pm 0.07^{\mathrm{a}}$ \\
\hline Asparagus horridus L. & $0.13 \pm 0.05^{b}$ & $0.51 \pm 0.06^{\mathrm{a}}$ & $0.07 \pm 0.00^{\mathrm{c}}$ & $0.23 \pm 0.04^{a}$ & $0.85 \pm 0.02^{\mathrm{a}}$ & $0.55 \pm 0.22^{b}$ & $0.74 \pm 0.12^{b c}$ & $0.77 \pm 0.02^{\mathrm{a}}$ & $0.69 \pm 0.11^{b}$ & $0.79 \pm 0.04^{c}$ \\
\hline Peganum harmala $\mathrm{L}$. & $0.04 \pm 0.00^{\mathrm{d}}$ & $0.13 \pm 0.00^{\mathrm{d}}$ & $0.09 \pm 0.02^{b}$ & $0.24 \pm 0.02^{\mathrm{a}}$ & $0.54 \pm 0.02^{\mathrm{d}}$ & $0.24 \pm 0.07^{\mathrm{d}}$ & $0.57 \pm 0.04^{\mathrm{d}}$ & $0.83 \pm 0.20^{\mathrm{a}}$ & $0.64 \pm 0.14^{\mathrm{b}}$ & $0.83 \pm 0.07^{b c}$ \\
\hline Launaea arborescens (Batt.) Murb. & $0.07 \pm 0.01^{\mathrm{c}}$ & $0.08 \pm 0.01^{\mathrm{d}}$ & $0.04 \pm 0.01^{\mathrm{d}}$ & $0.15 \pm 0.01^{b}$ & $0.48 \pm 0.02^{\mathrm{e}}$ & $0.36 \pm 0.06^{\mathrm{cd}}$ & $0.60 \pm 0.06^{\mathrm{cd}}$ & $0.78 \pm 0.16^{\mathrm{a}}$ & $0.76 \pm 0.05^{\mathrm{ab}}$ & $0.87 \pm 0.06^{b}$ \\
\hline Atriplex semibaccata R. Br. & $0.22 \pm 0.01^{\mathrm{a}}$ & $0.18 \pm 0.02^{c}$ & $0.15 \pm 0.02^{\mathrm{a}}$ & $0.13 \pm 0.03^{b}$ & $0.60 \pm 0.03^{b}$ & $0.50 \pm 0.02^{b c}$ & $0.76 \pm 0.11^{\mathrm{b}}$ & $0.60 \pm 0.10^{b}$ & $0.84 \pm 0.20^{\mathrm{a}}$ & $0.87 \pm 0.05^{b}$ \\
\hline
\end{tabular}

Values are expressed as mean $\pm \mathrm{SD}(n=3)$. Different letters in the same column designate significant differences $(p<0.05)$. 


\subsection{Candidate Local Plant Species for Phytostabilization}

The biplot of the principal component analysis (PCA) carried out on the concentrations of trace elements in the aboveground parts (shoots) of the five plant species (Figure 5a) accounted for $72.9 \%$ of the total variance. Dim 1 ( $43.6 \%$ of the total inertia) represents the capacity of the local plant species to accumulate diverse trace elements synchronously. It distinguished Atriplex semibaccata with high concentrations of $\mathrm{Cu}$ in its aboveground parts, and it separated Asparagus horridus with significant concentrations of $\mathrm{Cd}$ and $\mathrm{Zn}$ in its aboveground parts from the other plant species, namely, Vicia sativa, Peganum harmala, and Launaea arborescens, which contained lower concentrations of these trace elements. Dim2 (29.3\% of the total inertia) represents the concentration gradients of $\mathrm{As}, \mathrm{Cd}, \mathrm{Cu}, \mathrm{Ni}$, and $\mathrm{Zn}$ (Figure 5a). This dimension highlights a relevant affinity of Atriplex semibaccata for $\mathrm{Cu}$, and of Asparagus horridus for $\mathrm{Cd}$ and $\mathrm{Zn}$, which are separated from the other plant species that are only weakly correlated with $\mathrm{Cu}, \mathrm{Cd}$, and $\mathrm{Zn}$.
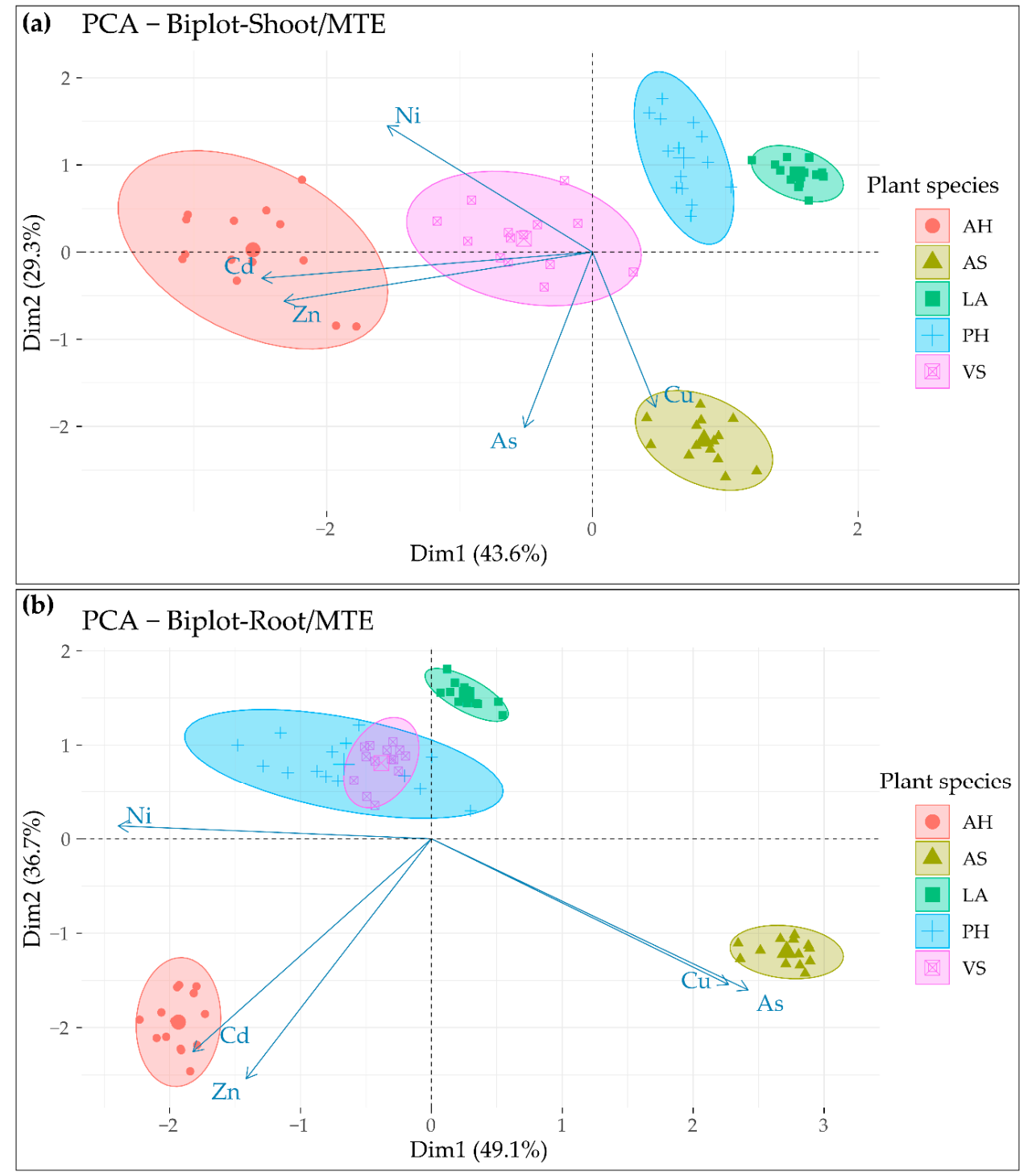

Figure 5. Principal component analysis (PCA) obtained for the concentrations of five metallic trace elements (MTEs) in the shoots (a) and the roots (b) of the plant species Asparagus horridus L. (AH), Atriplex semibaccata R. Br. (AS), Launaea arborescens (Batt.) Murb. (LA), Peganum harmala L. (PH), and Vicia sativa L. (VS). 
The biplot of the PCA carried out on trace elements in belowground parts (roots) of the plant species (Figure 5 b) explains $85.8 \%$ of the total variance. Dim 1 (49.1\% of the total inertia) explains the main information concerning the plant species' capability to accumulate different trace elements simultaneously (Figure 5b). Atriplex semibaccata presented a high concentration of $\mathrm{Cu}$ and As, and Aspragaus horridus had higher concentrations of $\mathrm{Cd}$ and $\mathrm{Zn}$; this indicated that the belowground parts of these plant species have accumulative capacity for these trace elements. The other plant species, namely Peganum harmala, Vicia sativa, and Launaea arborescens, had a preference for accumulating $\mathrm{Ni}$.

According to Krzesłowska [59] and Gajic et al. [60], the uptake of trace elements and their flow and translocation depends on their concentrations, availability in the substrate, local climatic conditions, and their affinity to plant species, as well as the plant species itself. Indeed, the reaction of metallic and metalloid trace elements differs from one element to another as well as from one plant species to another [54]. The intrinsic properties of each plant species, such as the adaptive mechanisms involved in the uptake and the translocation of trace elements, are considered the decisive factors of the affinity of plant species for trace elements [60]. Indeed, plant species differ from one another in the genetic expression of transporter genes controlling the absorption and efflux of trace elements through their tissues [61,62]. Therefore, the use of local wild plant species is highly recommended given that they are often genetically better equipped in terms of growth and the ability to reproduce under the prevailing environmental conditions $[49,50]$.

The plant species used in this experiment are predominantly perennial, namely, Asparagus horridus L., Atriplex semibaccata R. Br., Launaea arborescens (Batt.) Murb., and Peganum harmala L. According to Grime [63], these plant species have a long life cycle with high vegetative growth, which characterizes their K-selection strategy. Vicia sativa L. belongs to the legume plant family, which is considered a keystone of any plant community because of its ability for the fixation of atmospheric nitrogen by using bacteria (Rhizobium Frank 1889) [64]. This promotes the natural processes of plant establishment, increases their rate of growth, and improves soil recovery [60]. Asparagus horridus L., Atriplex semibaccata R. Br., and Launaea arborescens (Batt.) Murb. are known as plant species of semi-arid environments, and they are not very demanding in terms of water and nutrients; therefore, they also offer an interesting choice for the phytomanagement of a mining site in this environment [40]. These plant species are also important in the colonization of waste disposal sites because they adopt R-selection as a strategy of propagation by producing a large number of seeds $[50,60]$. According to Skousen et al. [65], these kinds of plant species can be competitive and their development delays the appearance of woody species which represent a threat to the long-term performance of SR cover made of PW.

\section{Conclusions}

The present field experiment demonstrated the high capacity of the five tested plant species, namely, Asparagus horridus L., Atriplex semibaccata R. Br., Launaea arborescens (Batt.) Murb., Peganum harmala L., and Vicia sativa L., to accumulate several trace elements, e.g., As, $\mathrm{Cd}, \mathrm{Cu}, \mathrm{Ni}$, and $\mathrm{Zn}$, with the highest concentrations in the belowground parts compared to those in aboveground part tissues. The concentrations of the studied element traces in the plant were below the domestic animal toxicity limits values, with careful consideration of the potential contamination of the trophic chain by cadmium. However, regarding the BCF and TF values, these local plants can be considered excellent candidates for the phytostabilization of PW. Atriplex semibaccata R. Br. presents a high affinity for $\mathrm{Cu}$ and As, Aspragaus horridus L. for Cd and Zn, whilst Peganum harmala L., Vicia sativa L., and Launaea arborescens (Batt.) Murb. possess a good tolerance to Ni. Overall, we conclude that the best candidates for establishing a plant community for the phytostabilization of PW and ensure the long-term performance of the SR cover are Atriplex semibaccata R. Br. and Vicia sativa L. as keystone species of the community, accompanied by Launaea arborescens (Batt.) Murb. and Peganum harmala L. 
Author Contributions: Conceptualization, A.O. and R.H.; methodology, H.Z. and A.O.; software, S.E. and H.Z.; validation, E.G.P., A.O., and R.H.; formal analysis, H.Z. and S.E.; investigation, H.Z., A.O., and R.H.; resources, A.O., R.H., H.Z., and S.E.; data curation, H.Z. and S.E.; writing-original draft preparation, H.Z.; writing-review and editing, A.O., E.G.P., R.H., L.M., and H.Z.; visualization, H.Z. and S.E.; supervision, A.O. and R.H.; project administration, A.O. and R.H.; funding acquisition, R.H. All authors have read and agreed to the published version of the manuscript.

Funding: This work was supported by: (i) the Moroccan Ministry of Higher Education (MESRSFC), (ii) the Centre National de Recherche Scientifique et Techniques-Rabat-Maroc (CNRST) under grant number PPR/2015/64, and (iii) the European Union's Horizon 2020 research and innovation program PANACEA, under the grant agreement No 773501 (www.panacea-h2020.eu).

Data Availability Statement: Data is contained within the article.

Acknowledgments: The authors would like to thank H. El Asri for assisting H.Z. with the fieldwork. Thanks are due to E. Outamamat (Ph.D. student), and the local authorities of the Kettara village. The authors are grateful to A. Diarra (Ph.D.), for his advice.

Conflicts of Interest: The authors declare no conflict of interest. The funders had no role in the design of the study; in the collection, analyses, or interpretation of data; in the writing of the manuscript, or in the decision to publish the results.

\section{References}

1. Khalil, A.; Hanich, L.; Hakkou, R.; Lepage, M. GIS-based environmental database for assessing the mine pollution: A case study of an abandoned mine site in Morocco. J. Geochem. Explor. 2014, 144, 468-477. [CrossRef]

2. United States Geological Survey (USGS). Mineral Commodity Summaries 2020; United States Geological Survey: Reston, VA, USA, 2020; ISBN 9781411343627.

3. Mehahad, M.S.; Bounar, A. Phosphate mining, corporate social responsibility and community development in the Gantour Basin, Morocco. Extr. Ind. Soc. 2020, 7, 170-180. [CrossRef]

4. Lottermoser, B.G. Mine Wastes: Characterization, Treatment and Environmental Impacts, 3rd ed.; Springer: Berlin/Heidelberg, Germany, 2010; ISBN 9783642124181.

5. Hamilton, S.J.; Buhl, K.J. Selenium in the Blackfoot, Salt, and Bear River Watersheds. Environ. Monit. Assess. 2005, 104, 309-339. [CrossRef] [PubMed]

6. Ouakibi, O.; Loqman, S.; Hakkou, R.; Benzaazoua, M. The Potential Use of Phosphatic Limestone Wastes in the Passive Treatment of AMD: A Laboratory Study. Mine Water Environ. 2013, 32, 266-277. [CrossRef]

7. Hakkou, R.; Benzaazoua, M.; Bussière, B. Acid mine drainage at the abandoned kettara mine (Morocco): 1 . Environmental characterization. Mine Water Environ. 2008, 27, 145-159. [CrossRef]

8. Moukannaa, S.; Loutou, M.; Benzaazoua, M.; Vitola, L.; Alami, J.; Hakkou, R. Recycling of phosphate mine tailings for the production of geopolymers. J. Clean. Prod. 2018, 185, 891-903. [CrossRef]

9. Haneklaus, N.; Bayok, A.; Fedchenko, V.; Kelley, R. Phosphate rocks and nuclear proliferation. Sci. Glob. Secur. 2017, 25, 143-158. [CrossRef]

10. Tulsidas, H.; Gabriel, S.; Kiegiel, K.; Haneklaus, N. Uranium resources in EU phosphate rock imports. Resour. Policy 2019, 61, 151-156. [CrossRef]

11. Hakkou, R.; Benzaazoua, M.; Bussie, B. Laboratory Evaluation of the Use of Alkaline Phosphate Wastes for the Control of Acidic Mine Drainage. Mine Water Environ. 2009, 206-218. [CrossRef]

12. Bossé, B.; Bussière, B.; Hakkou, R.; Maqsoud, A.; Benzaazoua, M. Assessment of Phosphate Limestone Wastes as a Component of a Store-and-Release Cover in a Semiarid Climate. Mine Water Environ. 2013, 32, 152-167. [CrossRef]

13. Hakkou, R.; Benzaazoua, M.; Bussière, B. Acid mine drainage at the abandoned kettara mine (Morocco): 2. Mine waste geochemical behavior. Mine Water Environ. 2008, 27, 160-170. [CrossRef]

14. Lottermoser, B.G. Recycling, reuse and rehabilitation of mine wastes. Elements 2011, 7, 405-410. [CrossRef]

15. Knidiri, J.; Bussière, B.; Hakkou, R.; Bossé, B.; Maqsoud, A.; Benzaazoua, M. Hydrogeological behaviour of an inclined store-andrelease cover experimental cell made with phosphate mine wastes. Can. Geotech. J. 2016, 54, 102-116. [CrossRef]

16. Bruneel, O.; Mghazli, N.; Hakkou, R.; Dahmani, I.; Filali Maltouf, A.; Sbabou, L. In-depth characterization of bacterial and archaeal communities present in the abandoned Kettara pyrrhotite mine tailings (Morocco). Extremophiles 2017, 21, 671-685. [CrossRef] [PubMed]

17. Bussière, B.; Aubertin, M.; Mbonimpa, M.; Molson, J.W.; Chapuis, R.P. Field experimental cells to evaluate the hydrogeological behaviour of oxygen barriers made of silty materials. Can. Geotech. J. 2007, 44, 245-265. [CrossRef]

18. Smirnova, E.; Bussière, B.; Tremblay, F.; Bergeron, Y. Vegetation succession and impacts of biointrusion on covers used to limit acid mine drainage. J. Environ. Qual. 2011, 40, 133-143. [CrossRef]

19. Mendez, M.O.; Maier, R.M. Phytostabilization of mine tailings in arid and semiarid environments-An emerging remediation technology. Environ. Health Perspect 2008, 116, 278-283. [CrossRef] 
20. Bolan, N.S.; Park, J.H.; Robinson, B.; Naidu, R.; Huh, K.Y. Phytostabilization. A Green Approach to Contaminant Containment; Academic Press: Cambridge, MA, USA, 2011; Volume 112, ISBN 9780123855381.

21. Aznar-Sánchez, J.; García-Gómez, J.; Velasco-Muñoz, J.; Carretero-Gómez, A. Mining Waste and Its Sustainable Management: Advances in Worldwide Research. Minerals 2018, 8, 284. [CrossRef]

22. Zine, H.; Midhat, L.; Hakkou, R.; El Adnani, M.; Ouhammou, A. Guidelines for a phytomanagement plan by the phytostabilization of mining wastes. Sci. Afr. 2020, 10, e00654. [CrossRef]

23. Heckenroth, A.; Rabier, J.; Dutoit, T.; Torre, F.; Prudent, P.; Laffont-Schwob, I. Selection of native plants with phytoremediation potential for highly contaminated Mediterranean soil restoration: Tools for a non-destructive and integrative approach. J. Environ. Manag. 2016, 183, 850-863. [CrossRef]

24. Midhat, L.; Ouazzani, N.; Hejjaj, A.; Ouhammou, A.; Mandi, L. Accumulation of heavy metals in metallophytes from three mining sites (Southern Centre Morocco) and evaluation of their phytoremediation potential. Ecotoxicol. Environ. Saf. 2019, 169, 150-160. [CrossRef] [PubMed]

25. Midhat, L.; Ouazzani, N.; Esshaimi, M.; Ouhammou, A.; Mandi, L. Assessment of heavy metals accumulation by spontaneous vegetation: Screening for new accumulator plant species grown in Kettara mine-Marrakech, Southern Morocco. Int. J. Phytoremediation 2017, 19, 191-198. [CrossRef] [PubMed]

26. Mahar, A.; Wang, P.; Ali, A.; Awasthi, M.K.; Lahori, A.H.; Wang, Q.; Li, R.; Zhang, Z. Challenges and opportunities in the phytoremediation of heavy metals contaminated soils: A review. Ecotoxicol. Environ. Saf. 2016, 126, 111-121. [CrossRef] [PubMed]

27. Barbosa, B.; Fernando, A.L. Aided Phytostabilization of Mine Waste; Elsevier Inc.: Oxford, UK, 2018; ISBN 9780128129876.

28. Gil-Loaiza, J.; White, S.A.; Root, R.A.; Solís-Dominguez, F.A.; Hammond, C.M.; Chorover, J.; Maier, R.M. Phytostabilization of mine tailings using compost-assisted direct planting: Translating greenhouse results to the field. Sci. Total Environ. 2016, 565, 451-461. [CrossRef] [PubMed]

29. Clemente, R.; Walker, D.J.; Pardo, T.; Martínez-Fernández, D.; Bernal, M.P. The use of a halophytic plant species and organic amendments for the remediation of a trace elements-contaminated soil under semi-arid conditions. J. Hazard. Mater. 2012, 223-224, 63-71. [CrossRef]

30. Parraga-Aguado, I.; Gonzalez-Alcaraz, M.N.; Alvarez-Rogel, J.; Jimenez-Carceles, F.J.; Conesa, H.M. The importance of edaphic niches and pioneer plant species succession for the phytomanagement of mine tailings. Environ. Pollut. 2013, 176, 134-143. [CrossRef]

31. National Academy of Sciences. Mineral Tolerance of Animals; Second Revised Edition; National Academies Press: Cambridge, MA, USA, 2005; ISBN 0309096545.

32. Larchevêque, M.; Desrochers, A.; Bussière, B.; Cartier, H.; David, J. Revegetation of Non-Acid-Generating, Thickened Tailings with Boreal Trees: A Greenhouse Study. J. Environ. Qual. 2013, 42, 351-360. [CrossRef]

33. Proteau, A.; Guittonny, M.; Bussière, B.; Maqsoud, A. Aboveground and belowground colonization of vegetation on a 17-year-old cover with capillary barrier effect built on a boreal mine tailings storage facility. Minerals 2020, 10, 704. [CrossRef]

34. Córdova, S.; Neaman, A.; González, I.; Ginocchio, R.; Fine, P. The effect of lime and compost amendments on the potential for the revegetation of metal-polluted, acidic soils. Geoderma 2011, 166, 135-144. [CrossRef]

35. Acosta, J.A.; Abbaspour, A.; Martínez, G.R.; Martínez-Martínez, S.; Zornoza, R.; Gabarrón, M.; Faz, A. Phytoremediation of mine tailings with Atriplex halimus and organic/inorganic amendments: A five-year field case study. Chemosphere 2018, 204, 71-78. [CrossRef]

36. Hamza, Z.; Rachid, H.; Mariam, E.A.; Kamal, L.; Sara, E.; Rachid, A.B.; Laila, M.; Papazoglou, E.G.; Kenza, L.; Mohamed, H.; et al. Phytostabilization of store-and-release cover made with phosphate mine wastes in arid and semiarid climate using wild local plants. Remediat. J. 2020, rem.21662. [CrossRef]

37. Aubert, G. Méthodes d'analyses des sols. In Centre National de Documentation Pédagogique, 2nd ed.; Centre Régional de Documentation Pédagogique de Marseille: Marsseille, France, 1978; p. 191.

38. Qualité du sol-Dosage des Eléments Traces dans des Extraits de sol par Spéctrométrie D'émission Atomique avec Plasma Induit par Haute Fréquence (ICP-AES); ISO 22036: Geneva, Switzerland, 2008.

39. Temminghoff, E.J.M.; Houba, V.J.G. (Eds.) Plant Analysis Procedures, 2nd ed.; Kluwer Academic Publishers: Dordrecht, The Nethrlands, 2004; ISBN 1402027699.

40. Ali, H.; Khan, E.; Sajad, M.A. Phytoremediation of heavy metals-Concepts and applications. Chemosphere 2013, 91, 869-881. [CrossRef]

41. Kabata-Pendias, A.; Pendias, H. Biogeochemistry of Trace Elements, 2nd ed.; CRC Press: Boca Raton, FL, USA, 2001 ; ISBN 0849315751.

42. Kabata-Pendias, A. Trace Elements in Soils and Plants; CRC Press: Boca Raton, FL, USA, 2010; p. 467.

43. Kloke, A.; Sauerbeck, D.R.; Vetter, H. The Contamination of Plants and Soils with Heavy Metals and the Transport of Metals in Terrestrial Food Chains. In Changing Metal Cycles and Human Health; Springer: Berlin/Heidelberg, Germany, $1984 ;$ pp. 113-141. [CrossRef]

44. De Luís, M.; Francisca García-Cano, M.; Cortina, J.; Raventós, J.; Carlos González-Hidalgo, J.; Rafael Sánchez, J. Climatic trends, disturbances and short-term vegetation dynamics in a Mediterranean shrubland. For. Ecol. Manag. 2001, 147, 25-37. [CrossRef]

45. Sakkir, S.; Shah, J.N.; Cheruth, A.J.; Kabshawi, M. Phenology of desert plants from an arid gravel plain in eastern United Arab Emirates. J. Arid Land 2015, 7, 54-62. [CrossRef] 
46. Bragato, C.; Brix, H.; Malagoli, M. Accumulation of nutrients and heavy metals in Phragmites australis (Cav.) Trin. ex Steudel and Bolboschoenus maritimus (L.) Palla in a constructed wetland of the Venice lagoon watershed. Environ. Pollut. 2006, 144, 967-975. [CrossRef]

47. Wong, M. Ecological restoration of mine degraded soils, with emphasis on metal contaminated soils. Chemosphere 2003, 50, 775-780. [CrossRef]

48. Conesa, H.M.; Moradi, A.B.; Robinson, B.H.; Kühne, G.; Lehmann, E.; Schulin, R. Response of native grasses and Cicer arietinum to soil polluted with mining wastes: Implications for the management of land adjacent to mine sites. Environ. Exp. Bot. 2009, 65, 198-204. [CrossRef]

49. Moreno-Jiménez, E.; Vázquez, S.; Carpena-Ruiz, R.O.; Esteban, E.; Peñalosa, J.M. Using Mediterranean shrubs for the phytoremediation of a soil impacted by pyritic wastes in Southern Spain: A field experiment. J. Environ. Manag. 2011, 92, 1584-1590. [CrossRef]

50. Zhang, Y.; Liu, J.; Zhou, Y.; Gong, T.; Wang, J.; Ge, Y. Enhanced phytoremediation of mixed heavy metal (mercury)-organic pollutants (trichloroethylene) with transgenic alfalfa co-expressing glutathione S-transferase and human P450 2E1. J. Hazard. Mater. 2013, 260, 1100-1107. [CrossRef]

51. Zheljazkov, V.D.; Jeliazkova, E.A.; Kovacheva, N.; Dzhurmanski, A. Metal uptake by medicinal plant species grown in soils contaminated by a smelter. Environ. Exp. Bot. 2008, 64, 207-216. [CrossRef]

52. Pandey, J.; Verma, R.K.; Singh, S. Suitability of aromatic plants for phytoremediation of heavy metal contaminated areas: A review. Int. J. Phytoremediation 2019, 21, 405-418. [CrossRef] [PubMed]

53. Lee, C.S.; Nzioka, A.M.; Kim, Y.J.; Sakong, J. Evaluation of bioconcentration factors of metals and non-metals in crops and soil from abandoned mines in Korea. Contemp. Probl. Ecol. 2017, 10, 583-590. [CrossRef]

54. El Hasnaoui, S.; Fahr, M.; Keller, C.; Levard, C.; Angeletti, B.; Chaurand, P.; Triqui, Z.E.A.; Guedira, A.; Rhazi, L.; Colin, F.; et al. Screening of native plants growing on a $\mathrm{Pb} / \mathrm{Zn}$ mining area in eastern Morocco: Perspectives for phytoremediation. Plants 2020, 9, 1458. [CrossRef] [PubMed]

55. Mattina, M.J.I.; Lannucci-Berger, W.; Musante, C.; White, J.C. Concurrent plant uptake of heavy metals and persistent organic pollutants from soil. Environ. Pollut. 2003, 124, 375-378. [CrossRef]

56. Nouri, J.; Lorestani, B.; Yousefi, N.; Khorasani, N.; Hasani, A.H.; Seif, F.; Cheraghi, M. Phytoremediation potential of native plants grown in the vicinity of Ahangaran lead-zinc mine (Hamedan, Iran). Environ. Earth Sci. 2011, 62, 639-644. [CrossRef]

57. Yoon, J.; Cao, X.; Zhou, Q.; Ma, L.Q. Accumulation of $\mathrm{Pb}, \mathrm{Cu}$, and $\mathrm{Zn}$ in native plants growing on a contaminated Florida site. Sci. Total Environ. 2006, 368, 456-464. [CrossRef]

58. von Willert, D.J.; Eller, B.M.; Werger, M.J.A.; Brinckmann, E. Desert succulents and their life strategies. Vegetatio 1990, 90, 133-143. [CrossRef]

59. Krzesłowska, M. The cell wall in plant cell response to trace metals: Polysaccharide remodeling and its role in defense strategy. Acta Physiol. Plant. 2011, 33, 35-51. [CrossRef]

60. Gajić, G.; Djurdjević, L.; Kostić, O.; Jarić, S.; Mitrović, M.; Pavlović, P. Ecological potential of plants for phytoremediation and ecorestoration of fly ash deposits and mine wastes. Front. Environ. Sci. 2018, 6, 1-24. [CrossRef]

61. Yang, X.; Feng, Y.; He, Z.; Stoffella, P.J. Molecular mechanisms of heavy metal hyperaccumulation and phytoremediation. J. Trace Elem. Med. Biol. 2005, 18, 339-353. [CrossRef]

62. Rai, P.K.; Kim, K.H.; Lee, S.S.; Lee, J.H. Molecular mechanisms in phytoremediation of environmental contaminants and prospects of engineered transgenic plants/microbes. Sci. Total Environ. 2020, 705, 135858. [CrossRef] [PubMed]

63. Grime, J.P. Plant Strategies and Vegetation Processes; John Wiley Sons, Ltd.: Chichester, UK; New York, NY, USA; Brisbane, Australia; Toronto, ON, Canada, 1979; 222p.

64. Reverchon, F.; Xu, Z.; Blumfield, T.J.; Chen, C.; Abdullah, K.M. Impact of global climate change and fire on the occurrence and function of understorey legumes in forest ecosystems. J. Soils Sediments 2012, 12, 150-160. [CrossRef]

65. Skousen, J.G.; Johnson, C.D.; Garbutt, K. Natural Revegetation of 15 Abandoned Mine Land Sites in West Virginia. J. Environ. Qual. 1994, 23, 1224-1230. [CrossRef] 